\title{
Translation Shift of Adverbs of Manner In Reference to: "City of Bones: Mortal Instruments" by Cassandra Clare
}

\author{
Jaynne Ilyanora Patricia ${ }^{1}$, Ida Bagus Putra Yadnya ${ }^{2}$, Ni Ketut Alit Ida Setianingsih ${ }^{3}$ \\ ${ }^{123}$ English Department - Faculty of Arts - Udayana University \\ 1.jaynneilyanorapatricia@gmail.com, ${ }^{2}$ putrayadnya@yahoo.com, ${ }^{3}$ alit_ida@yahoo.com \\ Denpasar, Bali, Indonesia
}

\begin{abstract}
This study is entitled "Translation Shift of Adverbs of Manner in Reference to 'City of Bones: Mortal Instruments' by Cassandra Clare". The aims are to identify the equivalences of adverbs of manner translated into Bahasa Indonesia and to analyze the shift of adverbs of manner in the novel. The data was collected by close-reading to identify the English adverbs of manner and its translation into Bahasa Indonesia found in the novel, highlighting the data found in both of the novels, comparing the data found to find the equivalences in both source and target language, then note-taking the data found to be analyzed afterward. The theories used in this research are the theory of translation proposed by Larson (1984) and the translation theory of shift proposed by Catford (2000). The results show that the English adverbs of manner found were equivalent to prepositions dengan, sambil, oleh, bagaikan, seperti, and secara that were followed with adjective, noun, verb, adjective phrase, noun phrase, verb phrase, or adverb after the preposition. The translation shift that occurred in the translation was category shift, in which the adverbs of manner shifted into an adjective, verbs, and numeral, and another type of translation shift that occurred was a level shift, in which adverbs of manner shifted adjective phrase, the noun phrase, and verb phrase.
\end{abstract}

Keywords: adverbs of manner, shift, translation

\section{INTRODUCTION}

The translation is one of the ways for a human to understand each other, specifically those who speak different languages. The English word "translation" derives from the Latin word translatio, which comes from the word trans (across) + ferre (to carry/to bring, which latio is the past participle of ferre). In other words, translation means "carrying across", which in this case a text from one language is 'carried across' into another language. According to Nida and Taber $(1982 ; 12)$, they see translating is a process of reproducing in the receptor language the closest natural equivalent of the source language message. Newmark (1991; 27), said that translating is the act of transferring the meaning of a unit of language from one language to another, whether it is a whole or part of the text. Thus, translation can be considered as a process of rendering meaning, ideas, or messages of a text from one language to another language.

In translating, it is important to understand the message that wants to be 
conveyed to avoid mistakes in the translation product. There is one thing that a translator needs to be aware of when conducting a translation process besides having an in-depth understanding of the intended message from the source language, yet the equivalency of the translation as well. According to Larson $(1984 ; 15)$, translation is classified into two main types; form-based and meaning-based. The form-based translation is known as literal translation, which attempts to translate every single word in a text. While meaning-based translation 'reproduce' the source language text in the most natural forms of the target language that will minimalize the 'awkwardness' or 'oddness' in the translation product to be understood by the target language readers. This kind of translation is also known as idiomatic translation. Thus, a good translator will try to translate idiomatically.

A paper entitled English Noun Phrase Translation Shift in the Novel "The Davinci Code" (Sugianti, 2017) described that there were category shift and the structural shift occurred in the process of translation. In her research, she found that there were three types of translation shift, which are classified into

(1) Unit Shift (from high to low level),

(2) Structural Shift (linguistic factor), and

(3) Intra-System Shift.

A journal of language and translation studies entitled The Structural Shift In "Gajah Selalu Ingat" (Iki, 2016) explained that there was structure shift in the subject, predicate, object, adverb, and compliment in the translation. It is also explained that in English sentences, there were modifiers that functioned as adjectives or adverbs, and head as the main word, and usually, in translating nouns into Bahasa Indonesia, the sentence structure changed, reversed from the English sentence structure. However, despite having the differences in the sentence structures, it is explained that the intended meaning of the source language into the target language was the same.

A paper entitled Translation Shift in Translating English Noun Phrases into Indonesian Noun Phrases Found in "Let It Snow" into "Dalam Derai Salju (Santiari, 2017) found that there were level shifts and category shift; included structure shift, class shift, unit shift, and intra-system shift). There were formbased translations and meaning-based translations found as well. Mostly, the translation shift that occurred was the structural shift and meaning-based translation (idiomatic translation) was dominated in the translation.

An undergraduate thesis entitled Translation Equivalence and Shift of Noun Phrases in the Novel The House on Hope Street and in Serpih - Serpih Harapan (Fitriyani, 2017) found equivalency in the translation known as formal correspondence and textualequivalency, and there were found 120 noun phrase in the analysis, 12 phrases of formal correspondences and 10 phrases of textual-equivalency. The shifts that occurred in the translation were structure shift, class shift, unit shift, and intrasystem shift.

Arisuta (2018) in his paper entitled Strategi Penerjemahan dan Pergeseran Makna Onomatope pada Lirik Lagu JKT48, stated that there were seven strategies of translation found to translate the onomatopoeias and the shift of meaning of onomatopoeias that was affected from using the translation strategy by paraphrasing.

Adnyana (2017) in his paper entitled Prepositional Phrases and Their Translation Shifts in Catching Fire in Tersulut found that the equivalency applied in translation were formal correspondences and textual equivalency, and the translation shifts that occurred in 
the translation were structure shift, class shift, unit shift, and intra-system shift.

A journal of language and translation studies entitled Shift of Noun Phrases in the Translation of The Fault In Our Stars into Indonesian Version (Putro, 2016) found that the types of translation shifts that occurred in the translation, and the shifts (category shift) occurred because there were differences in the noun phrase structure between English and Bahasa Indonesia, differences in word class, the number of components in a sentence and the differences between plural and singular terms in both languages.

A paper entitled Pergeseran Penerjemahan Idiom Pada Novel Oda Nobunaga Karya Sohachi Yamaoka (Muliani, 2016) explained that the types of translation shift were form-based shift and meaning-based shift.

An undergraduate thesis entitled Pergeseran Bentuk dan Makna Terjemahan dalam Cerpen Kappa Karya Akugatawa Ryunosuke (Krisna, 2018) found that class shift occurred in the translation and the translation process mostly using the literal translating technique.

Suryawati (2015), in her paper entitled Strategi Penerjemahan dan Pergeseran Makna Kosakata Budaya Material Pada Novel Densha Otoko Karya Nakano Hitori Serta Terjemahannya Dalam Bahasa Indonesia found that the shift of meaning that occurred due to the translation strategy used, which was cultural substitution.

Kurniawati (2014), through his study entitled Types, Function and Position of Adverbs In the Yak Magazine, found that there were several classifications of adverbs found and the position of adverbs were put in the sentence, such as at the beginning of a sentence, in the middle or at the end of the sentence.

Dianti (2016), in her paper entitled Penerjemahan Majas Metafora dalam
Novel Kaze No Uta Wo Kike Karya Haruki Murakami found that the metaphors were translated by keeping the metaphorical image, translated into simile, translated into figurative meaning with or without keeping metaphorical imagery, translated into a metaphor of receptor language and translated by adding the meaning explained. There were also several types of translation shifts found that were caused by the translation process from the source language into the target language.

Observing through the analysis and the results of these translation studies, most of these studies were using the translation theory of shifts proposed by Catford (2000), translation theory by Larson (1984), and some were using language structure and translation theory (Nida, 1975), theory of modulation proposed by Newmark (1988), translation strategies theory by Baker (1992), componential analysis theory proposed by Bell (1993), including the theory of grammar by Huddleston (1984), Quirk (1985) and Swan (1996). Shifts in translation were very commonly occurred as the results, whether it was a structure shift, level shift, or even a shift of meaning. Each component of words in a sentence has a big impact when the process of translation is conducted since every language has its terms, patterns, or rules. Thus, some words commonly will go missing from the source text when it is translated into the target language since it is important as a translator to maintain the original message to be transferred, rather than trying to keep the whole lexical items/components in a sentence remained when it is translated into the target language since it might make no sense, knowing that it might sound unnatural or odd in the target language's terms. 
Based on the foregoing introduction, the focus of this study is limited to the following problems:

a. What are the equivalences of adverbs of manner in Bahasa Indonesia found in the novel?

b. What types of shifts occur in the translation of the adverbs of manner found in the novel?

\section{MATERIAL AND METHOD}

In this study, the data were taken from a best-seller novel (based on the New York Times) entitled City of Bones: Mortal Instruments written in English by Cassandra Clare, while the translated version into Bahasa Indonesia by Melody Violin. This is a fantasy-adventure genre novel, consists of twenty-three (23) chapters and was published on March $27^{\text {th }}, 2007$ (in the U.S.) and July $2^{\text {nd }}, 2007$ (in the U.K.) by Margaret K. McElderry from Simon \& Schuster, Inc. while the translated version was published in February 2010 by Ufuk Press, Jakarta, Indonesia. This novel is very interesting to read since the author has a very unique way of describing and telling the story, by emphasizing the situation using the adverbs of manner, and it is very engaging for the readers as if they were there, having the adventure together with all those fictional characters. This novel was chosen because it provides a lot of English adverbs of manner and the translation process into the receptor language was quite interesting to be analyzed as cultural aspects were affecting the translation process. In collecting the data, the method and technique that were used were descriptive qualitative methods and by reading, notetaking, and highlighting the adverbs found in the novel and its translation.

First, the novel was read carefully, and repeatedly to identify and to collect the English adverbs of manner and its translation into Bahasa Indonesia.
Afterward, the collected data were classified into their translation equivalences using the theory proposed by Larson $(1984 ; 16-18)$ which is The Types of Translation. Lastly, the data will be analyzed further by using the Translation Theory of Shift by Catford (2000). Some of the data analyses were taken as a representative of the whole data found, which were presented in tables in the appendices section. The discussion of the analysis was descriptively written. Taking the conclusion was the last procedure of analyzing the data of this research.

\section{FINDING AND DISCUSSIONS}

3.1 The Translation Equivalences of Adverbs of Manner

The adverbs of manner found in the novel were classified into several equivalences, which were translated into preposition dengan, seperti, secara, yang, bagaikan, oleh, and sambil.

Each of the occurrences of this preposition was followed by adjective, noun, verb, noun phrase, verb phrase, adjective phrase, and even adverb.

\subsubsection{The Adverbs of Manner that} Equivalent with dengan

There were 47 adverbs of manner found that were translated using preposition dengan in the receptor language, and some of the data were being followed by an adjective (i.e. furiously into dengan kesal, properly into dengan jelas, etc.), being followed by a verb (i.e. dangerously into dengan berbahaya), being followed by adverbs (i.e. carefully and warily into dengan hati-hati), being followed by adjective phrase (i.e. narrowly into dengan lebih tajam), being followed by a verb phrase (i.e. handsomely into dengan cukup cakap) and being followed by a noun phrase (i.e. dizzily into dengan kepala pening, etc.). 
There were found some unique cases occurred that adverbs can shift meanings or functions such as perfectly normal into tidak ada yang berbeda, subtly strange into tidak kentara, most likely into yang paling mendekati, blindingly into yang menyilaukan.

3.1.2 The Adverbs of Manner that Equivalent with seperti

There were 3 adverbs of manner found that were translated using preposition seperti in the receptor language, and 2 data were being followed by a noun (i.e. ghostly translated into seperti hantu, etc.), and 1 data were being followed by a noun phrase (i.e. stupidly into seperti orang bodoh).

\subsubsection{The Adverbs of Manner that} Equivalent with secara

There were 3 adverbs of manner found that using preposition secara in receptor language (i.e. naturally translated into secara alami, etc.).

\subsubsection{The Adverbs of Manner that} Equivalent with bagaikan

The data found was the adverb of manner seemingly and translated into preposition bagaikan. There was no word followed after the preposition, as this preposition was an equivalent form of the translation of the adverb of manner seemingly.

\subsubsection{The Adverbs of Manner that} Equivalent with oleh

There was only 1 adverb of manner found that were translated using preposition oleh in receptor language (i.e. religiously translated into oleh agama).

\subsubsection{The Adverbs of Manner that} Equivalent with sambil

There were 5 adverbs of manner found that were translated using preposition sambil in receptor language (i.e. meditatively translated into sambil merenung, etc.).

\subsection{Category Shift of Adverbs of Manner}

Based on the data found in the novel, there were English adverbs of manner in which translation shifts occurred that is written as follow:

\subsubsection{Category Shift of Adverbs of Manner}

The category shift in the translation that was found were including adverbs of manner translated into an adjective, verb, noun, and into the numeral.

a. Adverbs of Manner translated into Adjective

There were 43 data found that were classified into category shift from adverb into an adjective. One of the data was taken and analyzed like this:

SL: He smiled smugly and lowered his hand.

TL: Jace tersenyum bangga dan menurunkan tangannya.

Smugly is an adverb marked by the suffix $-l y$ and modifies the verb smiled. It is translated into bangga in TL as an adjective. Thus, the adverb smugly shifts from adverb into an adjective.

b. Adverbs of Manner translated into Verb

There were 15 data found that were classified into category shift from adverb into a verb. One of the data was taken and analyzed like this:

SL: Isabelle froze, her spoon poised dangerously.

TL : Sendoknya terangkat dengan berbahaya.

Dangerously is an adverb marked by the suffix $-l y$ and modifies the adjective poised. It is translated into berbahaya in TL as a verb, which is formed from the prefix ber- + noun bahaya. In Bahasa Indonesia, the prefix ber-followed by 
noun will change its word-class into a verb. Berbahaya is considered as a verb because it shows an action of subject Isabelle who was surprised but maintained to compose herself.

\section{c. Adverbs of Manner translated into Numeral}

There were 7 data found that were classified into category shift from adverb into the numeral. One of the data was taken and analyzed like this:

SL: "That's not entirely true," Hodge said.

TL: "Itu tidak sepenuhnya benar," kata Hodge.

Entirely is an adverb of manner marked by the suffix $-l y$ and modifies adjective true. It is translated into sepenuhnya in TL which belongs to numeral as it is having the same meaning as whole or fully.

\subsubsection{Level Shift of Adverb of Manner}

The level shift in the translation that was found are including adverbs of manner translated into an adjective phrase; into verb phrase; into noun phrase and adverb phrase.

a. Adverbs of Manner shifted into Adjective Phrase

There were 9 data found that were shifted from adverbs of manner into an adjective phrase. One of the data was taken as representative and analyzed like this:

SL: Hodge jerked upright, so abruptly that Hugo, who had been resting comfortably on his shoulder, launched himself into the air with an irritable claw. TL: Hodge tersentak ke atas, sangat keras sehingga Hugo yang tadinya beristirahat dengan nyaman di pundaknya, melompat ke udara dengan kaokan kesal.

Abruptly is an adverb of manner marked by the suffix $-l y$. It is translated into sangat keras in TL, which is formed from the adverb sangat + adjective keras. In this case, sangat has the same meaning as adverb very and keras has the same meaning as the adjective hard (very hard). The adverb sangat modifies the adjective keras, thus the adverb abruptly shifts into an adjective phrase.

b. Adverbs of Manner shifted into Noun Phrase

There were 9 data found that were shifted from adverbs of manner into a noun phrase. One of the data was taken as representative and analyzed like this:

SL: She laughed, standing over him, and dizzily he thought that he should have known.

TL: Dengan kepala pening, pemuda itu berpikir bahwa seharusnya dia sudah tau.

Dizzily is an adverb of manner marked by the suffix $-l y$. Adverb dizzily modifies the subject $h e$, and it is translated into dengan kepala pening in TL, which is formed from preposition dengan + noun kepala + adjective pening. The adjective pening modifies the noun kepala, thus the adverb dizzily shifts into a noun phrase.

\section{c. Adverbs of Manner shifted into Verb Phrase \\ There were 4 data found that were} shifted from adverbs of manner into a noun phrase. One of the data was taken as representative and analyzed like this:

SL: The runes are agonizingly painful.

TL: Rune sangat menyiksa dan menyakitkan.

Agonizingly is an adverb marked by the suffix $-l y$ and modifies the adjective painful. It is translated into sangat menyiksa dan menyakitkan, which is formed from adverb sangat + verb menyiksa. Dan menyakitkan is a translation of adjective painful as a complementary because without being translated, the sentence still makes sense 
and understandable. Thus, the adverb agonizingly shifts from adverb into verb phrase.

\section{CONCLUSIONS}

Based on the foregoing discussions, there were several conclusions regarding the topic which has been analyzed. The conclusions are described as follows: The equivalent translation of English adverbs of manner that are found in the novel are using prepositions dengan, seperti, secara, bagaikan, oleh, and sambil. In each of these prepositions, there are some adjectives, verbs, nouns, noun phrases, adjective phrases, or even adverbs followed after the prepositions. There are also unique cases found, which are the occurrence of double negatives statements and adverbs of manner which shifted its function into adverb of degree and adjectives.

There are two types of shifts that occurred in the translation of adverbs of manner found in the novel; category shift and level shift. In category shift, the translated adverbs of manner are shifted into adjectives, verbs, and numerals. In level shift, the translated adverbs of manner are shifted into adjective phrases, noun phrases, and verb phrases.

Observing from the result and the analysis of this study, English of adverbs of manner that are translated are mostly into or being followed with adjectives, even from both types of translation shifts. In this case, it can be concluded that the translation of English adverbs of manner are mostly equivalent with the adjectives in Bahasa Indonesia, although it may be followed or translated into other word class (verb, noun, verb phrase, adjective phrase, noun phrase, verb phrase, etc.) but usually, in its translation will occur affixes to form the word in the sentence.

\section{REFERENCES}

[1] Arisuta, Citra. 2018. Strategi Penerjemahan dan Pergeseran Makna Onomatope pada Lirik Lagu JKT48. Humanis Journal of Arts and Humanities. Vol. 22.2. May 2018: 335-341.

[2] Carter, Ronald; McCarthy, Michael (2006), Cambridge Grammar of English: A Comprehensive Guide, Cambridge University Press.

[3] Catford, J. C. 1965. A Linguistic Theory of Translation. London: Oxford University Press.

[4] Clare, Cassandra. 2007. City of Bones: The Mortal Instruments. New York: Simon \& Schuster, Inc. Ebook version available from: https://epdf.pub/cityof-bones-the-mortal-instruments.html.

[5] Choliludin. 2005. The Technique of Making Idiomatic Translation. Bekasi: Kesaint Blanc.

[6] Dianti, Ni Gusti Putu Wahyu. 2016. Penerjemahan Majas Metafora dalam Novel Kaze No Uta Wo Kike Karya Haruki Murakami. Humanis Journal of Arts and Humanities. Vol. 16.2. August 2016: 122129.

[7] Faculty of Computer Science. Kamus Besar Bahasa Indonesia. 2018. Jakarta: University of Indonesia. Available from: http://bahasa.cs.ui.ac.id/kbbi/kbbi.php?keyword=te rkendali\&varbidang=all\&vardialek=all\&varragam =all\&varkelas=all\&submit=kamus.

[8] Fitriyani, Ayu. 2017. Translation Equivalence and Shift of Noun Phrases in the Novel The House on Hope Street and in Serpih - Serpih Harapan. Humanis Journal of Arts and Humanities. Vol. 18.1. February 2017: 1-9.

[9] Iki, Yunia. 2016. The Structural Shift In "Gajah Selalu Ingat". Humanis Journal of Arts and Humanities. Vol. 17.1. October 2016: 282-288.

[10] Krisna P., Ni Putu Ayu. 2018. Pergeseran Bentuk dan Makna Terjemahan dalam Cerpen Kappa Karya Akugatawa Ryunosuke. Humanis Journal of Arts and Humanities. Vol. 22.4. November 2018: 1009-1017.

[11] Kurniawati, I Gusti Ayu Dewi. 2014. Types, Function, and Position of Adverbs In the Yak Magazine. Humanis Journal of Arts and Humanities. Vol. 8.2. August 2014: 2302-920.

[12] Language Development and Fostering Agency. KBBI Daring. 2016. Jakarta: Ministry of Education and Culture of Republic Indonesia [Internet]. Available from: https://kbbi.kemdikbud.go.id/.

[13] Larson, M. L. 1984. Meaning-Based Translation: A Guide to Cross-Language Equivalence. Lanham Md: University Press of America.

[14] Mulyani, Putu Ayu. 2016. Pergeseran Penerjemahan Idiom Pada Novel Oda Nobunaga Karya Sohachi Yamaoka. Humanis Journal of Arts and Humanities. Vol. 14.1. January 2016: 104-111. 
[15] Pullum, G., \& Huddleston, R. (2002). The Cambridge Grammar of the English Language. Cambridge: Cambridge University Press.

[16] Putro, Rico Yulianto. 2016. Shift of Noun Phrases in the Translation of The Fault In Our Stars into Indonesian Version. Humanis Journal of Arts and Humanities. Vol. 17.1. October 2016: 257-264.

[17] Santari, Ni Wayan. 2017. Translation Shift in Translating English Noun Phrases into Indonesian Noun Phrases found in "Let It Snow" into "Dalam Derai Salju". Humanis Journal of Arts and Humanities. Vol. 19.1. March 2017: 236-243.

[18] Sugianti, Desak. 2017. English Noun Phrase Translation Shift in the Novel "The Davinci Code". Humanis Journal of Arts and Humanities. Vol. 3.5. March 2017: 2540-8720.

[19] Suryawati, Anak Agung Sagung. 2015. Strategi Penerjemahan dan Pergeseran Makna Kosakata Budaya Material Pada Novel Densha Otoko Karya Nakano Hitori Serta Terjemahannya Dalam Bahasa Indonesia. Humanis Journal of Arts and Humanities. Vol. 13.3. December 2015: 2302-920.

[20] Tri Adnyana, I Dewa Nyoman. 2017. Prepositional Phrases and Their Translation Shifts in Catching Fire and in Tersulut. Humanis Journal of Arts and Humanities. Vol. 18.1. February 2017: 127-134. 